IJTC

Ilomata International Journal of Tax \& Accounting

P-ISSN: 2714-9838; E-ISSN: 2714-9846

Vol. 1 No. 3 July 2020

https://www.ilomata.org/index.php/ijtc

\title{
The Influence of Information Technology Covid-19 Plague Against Financial Statements and Business Practices
}

\author{
Hertati Lesi ${ }^{1}$, Otniel safkaur ${ }^{2}$ \\ 1. Lecturer, Departement of Accounting, STIE Rahmaniyah - Indonesia \\ ${ }^{2}$ Department of Accounting, Universitas Cendrawasih, Indonesia, \\ Correspondent: hertatilesi@yahoo.com.id
}

Submitted : June 6, 2020 Revised : July 1,2020 Published : July 30,2020

\begin{abstract}
The covid-19 Information Technology develops virtually rapidly, where technology makes users able to interact with an online- simulated environment of tools that have a number of accurate information that can be accessed online to receive information. Information Technology covid-19 cause dampak adverse impact on micro small and medium business activities so that the impact goods can be using, consider the performance targets in addition to the declining profit for the company because it does not obtain sales transactions in the end the flow of funds from customers more inhibited. Covid-19 epidemics effect reduced. The Company's financial statements and business practices and profitabity according to. Information Exposition of covid-19 caused the customer to take the decision to well at home. There are no activities beyond the end of business practices and other transactions for the Company. Media public like Web, private social networks, wiki and blog become tools for companies that are important for communication, collaboration, and sharing information about sales through the system even directly evaluations How sales take place. The data analysis techniques used in this study are Structural Equation Modeling (SEM) techniques, in micro small and medium Enterprises in Indonesia related and accumulated 112 samples conducted micro small and medium Enterprises spread across Indonesia. The results showed that the information technology covid-19 plague information technology had considerable effect on the company's financial statements and business practices. Companies should consider the losses caused by the inventory and the company's revenues will decline. The research was conducted on Micro Small- medium Enterprises in Indonesia which impact the corona pandemic.
\end{abstract}

Keyword: Information Technology Covid-19 plague, Company's financial performance, business practices.

\section{INTRODUCTION}

Information is needed by the organization in order to make effective decisions to support the needs of the Organization (Susanto, 2017: Albertini 2014: Hertati, 2020). Then

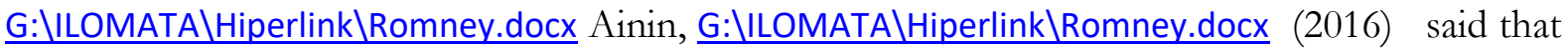
to make an effective decision, the Organization must decide what decisions are made, what information is needed and how to collect and process data to generate information. G:|ILOMATA|Hiperlink\Meleod.I.docxArnfalk (2016), said that Information Technology can provide competitive advantage (compatitive Advantage) for the company. However Impact technologically information covid-19 adversely bad affects. Financial reporting and business Ventures itself because Corona outbreak caused the purchasing power of the community to 
The influence of information technology covid-19 plague against Financial Statements and Business Practices Lesi \& Safkaur

decrease where Office activities and sales activities were discontinued due to Corona epidemic so that data processing results could give meaning and benefits causing financial reporting of business activities to be bad, while data is a fact or anything that can be used as input in generating information (Susanto, 2017) In line with the above understanding, G:|ILOMATA|Hiperlink\McLeod.docxAsadi (2017), Information Technology Covid-19 adversely impacts the preparation of merchandise into using and employees in the Government's appeal to dwell on this matter is a fact and a number that is usually meaningless and still not processed, while information is the result of data processing that has meaning, usually tell a thing that is not known by the user. Then according to G:IILOMATA\Hiperlink\Hall.docxargyres, (1999) information is business resource. Such as other business sources: raw materials, capital, and Labor, information is essential and indispensable to the survival of today's business organizations (Barua, 1995)."

In fact, the phenomenon states that the information produced by the company is not qualified, as was discovered by the Finance Minister Mulyani (2009). He doubted the quality of information provided by Bank Indonesia on bank inspection in Indonesia. Then Boediono (2010) as Vice president reminded that the Bank should make a quality report. He asserted that quality information is very important, the banking financial statements must be accurate and do not do window dressings (Polish financial statements) to look good. The impact of the Covid-19 information can affect business sales so that a covid-19 outbreak affects the sales business and financial statements of sales as well as employee performance by Can (Bai, 2017). Berkhout (2001) says the information technology is a system consisting of a collection of integrated computer-based components and manual components that are made to collect, store and manage data and provide information output to users. Information technology is a specialized subsystem of information systems aimed at collecting, processing and reporting on information relating to financial aspects of business activities (Borghans, ET, all, 2009).

The phenomenon of low transparency and Accountability of the state's financial statements, resulted in the opinion given by the CPC against the state's financial Statements is not giving the opinion (disclaimer). Basic reason BPK gave the opinion Disclaimer One of which is still weak accounting information system and state reporting. Nasution (2009) also stated that BPK rediscovered nine points relating to the opinion of the disclaimer of Central Government Financial statements. One of these is the absence of an alignment between the general Accounting information system held by the Department of Finance and accounting Information System of the agency held by the department/institution, so there is still difference between the two.

Next, the chairman of the Bank Century investigative audit team from the financial inspectors (BPK) Hasan Bisri (2010) said that there is a bank game and accounting Engineering in the case of the Century bank. The banker's game, the bank was made of loss, was disengaged from the inside and the account was engineered as if the assets were good '. Accounting engineering is done that the true asset is not worth it but it is considered high value. Further Hasan Bisri (2010) said the century bank case occurred due to an unyielding in the application of Bank Indonesia provisions. Other phenomena say that there are seven issuers who belong to the Bakrie group have deposits/time deposits at PT. Bank Capital Indonesia amounting to 6.7 trillion, but Bank Capital's financial statements in the same period record the deposits of customers in the Bank of only 2.69 trillion. According to Harry Nadir (2010) as the finance director of UNSP, the fund has been withdrawn to finance the acquisition, but due to the administrative problems of the funds are still recorded in the one Quarter financial report. Therefore, Ito Warsito (2010) as the main 
The influence of information technology covid-19 plague against Financial Statements and Business Practices Lesi \& Safkaur

director of the Indonesia Stock Exchange (IDX) said: ' The Bakrie group issuer incorrectly implements the accounting standards, if the Bakrie group's issuer has withheld the supposed funds on the date of the withdrawal noted in the financial statement'.

Management within an organization works to process all accounting information that is a key part of a set of information (Bose 2011). Accounting information used appropriately is a tool in making good business decisions (Busch et al, 2001). Good business decisions are made by using quality information (Bergeron, Bergeron,2008). Quality information is one of the competitive advantages of an organization (Chen, et.al, 2011). The competitive advantage of an organization is a unique characteristic of a company in producing superior products and superior in decision making than its competitors (Chuang, et.al, 2016). The decision making of quality is strongly influenced by quality information (casolaro, et.al, 2007).

Information systems obtained from information technology and in designing information technology in strategic ways that are needed to be integrated with high capability in all service groups appropriately for data management for precise decision making. This concept was expanded by Croson, et.al (2009, i.e. becoming the supporting capacity of Mobile Wireless ad hoc networks devices and methods. The Next Research, Chen, (2007), uses the concept of infrastructure support as a unified support for the ease of electronic-based business transactions and ease of management. Strictly Ciborra (1997) says that facilities are very important in the service of information technology has become a common expression around the world ". In a broader perspective, Hertati (2015) confirms information technology is a feature of information technology era and technology communication related to Internet network.

Its funding and the launch of new pastility, especially broadband communications network with national Reach became a strategic issue in small micro-medium business services. Generally in developing countries the guarantee of the maintenance of the supply has not been in accordance with expectations including for small micro enterprises. In a nutshell, both new and maintenancebuilding processes involve: Environmental change, funding, ownership and post-management of large economies of scale; Changed access methods; And the governance of the supply and supply of pastility has not been in accordance with expectations including for small micro Enterprises (Ciliberto,2006: Crichton,1995).

\section{METHOD}

The location of this research is Micro Small Medium Enterprises in Indonesia population, namely sales, finance and IT. The total population in this study amounted to 45 samples taken using the Slovin formula with a 5\% error rate with a sample amount of 200 respondents. From a questionnaire that was spread out as much as 200, the return was as much as 105 and that can be processed as many as 102 questionnaires, as many as 3 respondents filling incomplete. This research uses quantitative methods with multiple regression analysis tools. The tool used is SPSS version 2.4. Scales used to use the five-point Likert scale (Hair, et.al, 1998)

\section{RESULT AND DISCUSSION}

The independent variables in this study were information technology outbreak of Covid$19\left(\mathrm{X}_{1}\right)$, and against financial statements and business practices $(\mathrm{Y})$ as a variable of its dependencies. These variable relationships can be described systematically as follows:

$$
\text { Yof }\left(X_{1}\right)
$$


The influence of information technology covid-19 plague against Financial Statements and Business Practices Lesi \& Safkaur

Table 1. Variable Dimensions and Indicator

\begin{tabular}{|c|c|c|c|}
\hline No. & Conceptual definitions & Dimensions & Indicator \\
\hline 1. & $\begin{array}{l}\text { Information technology outbreak Covid-19: } \\
\text { Execution of interaction restrictions } \\
\text { When the number of sufferers } \\
\text { Covid-19 in Indonesia continues to surge }\end{array}$ & Involvement & $\begin{array}{l}\text { 1. Provide events } \\
\text { 2. Impression } \\
\text { 3. the There is an object } \\
\text { 4. the Impression } \\
\text { 5. the Can be seen } \\
\text { 6. Important } \\
\text { 7. Relevant } \\
\text { 8. Strengths } \\
\text { 9. Knowledgeable } \\
\text { 10. the Into products }\end{array}$ \\
\hline 2. & $\begin{array}{l}\text { Financial statements and business practices : } \\
\text { the report system is set up for users after } \\
\text { transactions are recorded and summarized } \\
\text { within one accounting period. }\end{array}$ & $\begin{array}{l}\text { Profitability } \\
\text { Market Share } \\
\text { Cost } \\
\text { Reduction }\end{array}$ & $\begin{array}{l}\text { 11. Gross profit. } \\
\text { 12. Product Price, } \\
\text { 13. Selling products } \\
\text { 14. Expanding The market Area } \\
\text { 15. Production costs } \\
\text { 16. Number of products }\end{array}$ \\
\hline
\end{tabular}

Source: Result and discussion of variable dimensions and induces, 2020

Research questioner is tested using SPSS Ghozali and Fuad. 2005, and the research results show that all questionnaires are said to be valid and reliable. Reliability is to measure a questionnaire that is an indicator of a variable or a construct. Questions are said to be reliable or powerful when a person's answer to the question is consistent. In determining significant or insignificant with Mrmcompare the value of $R$ count with the value of $R$ table degree of freedom $=n-K$, and the area side testing with Alpha 0.05. If $\mathrm{r}$ counts each question item is positive and is greater than the $\mathrm{R}$ table (see corrected item-Total correlation) Then the question item is said to be valid. From the output analysis on the above reusability test, see the corrected item-Total correlation is the value of $\mathrm{R}$ count for each question item of each variable. The value of $\mathrm{R}$ count each item is both positive and negative and the value is greater than $r$ table, hence the summed of the variable statement item in say is valid. Result value is valid because the Rcalculated $>\mathrm{R}$ table. The validity test results can be seen in table 2 .

Table 2. The results of this study show that all questionnaires are valid and reliable

\begin{tabular}{|ccccc|}
\hline Variable & Indicator & R value & Significance & Description \\
\hline & X1 & $.624^{* *}$ & .000 & Valid \\
& X2 & $.806^{* *}$ & .000 & Valid \\
& X3 & $.754^{* *}$ & .000 & Valid \\
& X4 & $.833^{* *}$ & .000 & Valid \\
Information technology outbreak Covid-19 & X5 & $.731^{* *}$ & .000 & Valid \\
& X6 & $.787^{* *}$ & .000 & Valid \\
& X7 & $.815^{* *}$ & .000 & Valid \\
& X8 & $.765^{* *}$ & .000 & Valid \\
& X9 & $.880^{* *}$ & .000 & Valid \\
& X10 & $.804^{* *}$ & .000 & Valid \\
\hline \multirow{3}{*}{ Financial statements and business practices } & X11 & $.788^{* *}$ & .000 & Valid \\
& X12 & $.860^{* *}$ & .000 & Valid \\
& X13 & $.865^{* *}$ & .000 & Valid \\
& X14 & $.853^{* *}$ & .000 & Valid \\
& X15 & $.749^{* *}$ & .000 & Valid
\end{tabular}


The influence of information technology covid-19 plague against Financial Statements and Business Practices Lesi \& Safkaur

$\begin{array}{lll}\mathrm{X} 16 & .855^{* *} \quad .000 \quad \text { Valid }\end{array}$

For the reliability test, if the value of alpha $>0.90$ It is said to be perfect reliability, if alpha between $0,70-0,90$ then called by high reliability. If the alpha is $0.50-0,70$ then it is called moderate, and when the alpha value is $<0.50$ then the reliability is low. The test results show that the alpha value of the entire questionnaire $>0.90$, it shows that it is in the category of perfect reliability.

Table 3. Reliability test Results

\begin{tabular}{|c|c|c|c|}
\hline No & Variable Let & Cronbach's Alpha & Description \\
\hline $\begin{array}{l}1 \\
2\end{array}$ & $\begin{array}{l}\text { Information technology outbreak Covid-19 } \\
\text { Company's financial performance \& business } \\
\text { Practices }\end{array}$ & $\begin{array}{l}.943 \\
.847\end{array}$ & $\begin{array}{l}\text { Reliable } \\
\text { Reliable }\end{array}$ \\
\hline
\end{tabular}

Source: Data SPSS, 2020

The influence of inter-variable independent (Organizational Commitment) to variable dependent (financial statements and business practices) Micro Small Business in Indonesia can be seen from the results of $T$ hitug between variable and $\mathrm{R}$ square value. Coefficient of determination is zero and one. A small R2 value means variable deterioration - independent variables in explaining the variation of dependent variables is very limited. A value close to one means the variable - Independent variables provide almost all the information needed to predict the variation of the dependent variable. The results of the T-Test count and Nili R Square This research can be seen in table 4.

Table 4. Test result t count and significance value

\section{Coefficients $^{\mathrm{a}}$}

\begin{tabular}{|l|r|r|r|r|r|}
\hline \multirow{2}{*}{ Model } & \multicolumn{2}{|c|}{ Unstandardized Coefficients } & Standardized Coefficients & \multirow{2}{*}{ Sig. } \\
\cline { 2 - 5 } & \multicolumn{1}{|c|}{ B } & Std. Error & Beta & T \\
\hline 1(Constant) & 11.575 & 4.744 & 2.440 & .000 \\
Information technology outbreak Covid-19 & 1.239 & 4.162 & .182 & 4.010 & .000 \\
Company's financial performance \& & 1.186 & .230 & .635 & 4.154 & .000 \\
business Practices & & & & \\
\hline Nilai r square: 0,636 & & & \\
\hline
\end{tabular}

Source: SPSS Data, 2020

Based on the data obtained it is known that it counts the variables of the calculated $t$ variable the organization 's commitment $>t$ value table, which is $4,010>1.985$, this result shows that the organizational Commitment is influential in the financial statements and business practices of small micro-medium Enterprises in Indonesia. The $\mathrm{R}$ square value is obtained at 0.636 or $63.6 \%$ which implies a percentage of contributions influence the independent variable against the dependent variable by $63.6 \%$. The $\mathrm{F}$ test on a study served to figure out the influence of a shared independent variable-against dependent variables.

Table 5. Test value $\mathrm{F}$

\begin{tabular}{|ll|r|r|r|c|c|}
\hline Model & & Sum of Squares & Df & Mean Square & F & \multicolumn{1}{c|}{ Sig. } \\
\hline 1 & Regression & 16358.509 & 2 & 8179.255 & 83.133 & $.000^{\mathrm{a}}$ \\
& Residual & 9346.838 & 95 & 98.388 & & \\
& Total & 25705.347 & 97 & & & \\
\hline
\end{tabular}

A. Predictors: (Constant), Information Technology of Covid-19 outbreak

B. Dependent variables: Company's Financial performance \& business Practices 
The influence of information technology covid-19 plague against Financial Statements and Business Practices Lesi \& Safkaur

Based on the results of the F-test data, it can be concluded that the test value of $\mathrm{f}$ means that there is a variable influence on The organization's commitment to financial statements and business practices . From the results explained that hypotheses in this study were received. In addition to the $\mathrm{F}$ test, in order to know the relationship between dimensions of each variable, the correlation between dimensions is calculated. The correlation between dimensions can be seen in table 6.

Table 6. Dimension Intercorrelation

\begin{tabular}{|clccc|}
\hline & Dimensions & Y1.1 & Y1.2 & Y1.3 \\
\hline X1.1 & Identification & $.784^{* *}$ & $.681^{* *}$ & $.711^{* *}$ \\
X1.2 & Involvement & $.737^{* *}$ & $.657^{* *}$ & $.579^{* *}$ \\
Y1.1 & Profitability & 1 & $.692^{* *}$ & $.740^{* *}$ \\
Y1.2 & Market Share & $.752^{* *}$ & 1 & $.886^{* *}$ \\
Y1.3 & Cost Reduction & $.760^{* *}$ & $.886^{* *}$ & 1 \\
\hline
\end{tabular}

Source: Data SPSS, 2020

Based on the results of the data, it can be seen that each variable between dimensions has a strong enough relationship. Table 4 shows that the correlation between the engagement dimension has the strongest relationship with the main factor dimensions in the work, as well as the dimension of Loyalty has the strongest relationship with the same dimensions, the main factor in working. And the system usage dimension has a strong relationship with the system quality dimension of the information usage factor.

Teixeira Research, et, all, 2008: hertati, (2015) the sales ingredient does not necessarily provide a comparable increase in profits, at some point . The Increase in results will be reduced even though the sales factor continues to be added. Infrastructure availability makes it easy for companies to make decisions When markets are saturated or over capacity products that ultimately affect the financial structure and profitability. Customers have a number of Accurate information that can be accessed online to purchase purchases. Stewart's research, (2007), Law (2005), Koontz,(2005, Hertati, et.al, (2019). The Enterprise gets faster transactions and ultimately flows the funds from customers faster. Improve the company's financial structure and profitability. Infrastructure availability makes it easy for customers to take accurate and timely decisions and ultimately close transactions that benefit the company. In addition to the use of Public Media by companies on the Web, private social networks, wikis and blogs are becoming an important enterprise tool for communication, collaboration, and sharing information about efforts to increase sales through the system even evaluating directly how sales take place.

\section{CONCLUSION}

Based on the results of research technology influence of Covid-19 epidemics against financial statements and business practices with the data obtained researchers then concluded that the Long term measures require IT availability so that strategic decision making can be implemented with the right information as well as a safe and transparent process. Companies can move quickly including anticipating changes with the right strategy. Availability and IT support is to reengineer business strategies to make business processes more flexible and adaptive to change. Through IT support the company operates in a wider area with more customer reach and ultimately increases profitability as well as financial structures. Micro small Medium Enterprises obtain a flow of funds from the sale of business Services faster and improve the financial structure with the support of IT but experiencing kandalah the effect of covid-19 infectious viral epidemics from people to others are encouraged by the government to dwell in the home and business activities decreased so that the merchandise experienced a decrease in sales turnover and losses due to the stock of the goods experiencing the decay and Company as a mediator of strategic relations with performance. Strategy implementation capabilities positively impact performance. The sales operating system of business companies has changed the high-speed wireless Wi-Fi networks, and 
The influence of information technology covid-19 plague against Financial Statements and Business Practices Lesi \& Safkaur

laptop computers and wireless tablets. Companies can increase sales by more customer reach. Infrastructure growth makes customers have access to products online and closes transactions. Information technology as a unified tool for ease of electronic based business transactions and the ease for management included in sales oriented to increased profits.

\section{REFERENCE}

Albertini, E. (2014). A descriptive analysis of environmental disclosure: A longitudinal study of French companies. J. Bus. Ethics 121(2), 233-254.

Ainin, S., Naqshbandi, M.M., Dezdar, S. (2016). Impact of adoption of Green IT practices on organizational performance. Qual. Quant. 50 (5), 1929-1948.

Arnfalk, P., Pilerot, U., Schillander, P., Gronvall, P. (2016). Green IT in practice: virtual meetings in Swedish public agencies. J. Clean. Prod. 123, 101-112.

Asadi, S., Hussin, A.R.C., Dahlan, H.M. (2017). Organizational Research in the Field of Green IT: A Systematic Literature Review from 2007 to 2016. Telemat. Inform. 37 (4), 1191-1249.

Argyres, N. S. (1999), The impact of information technology on coordination: evidence from the B-2 stealth bomber, Organization Science, 10(2), 162-180.

Barua, A., Kriebel, C.H. \& Mukhopadhyay, T. (1995), Information technologies and business value: an analytic and empirical investigation, Information Systems Research, 6(1), 3-23

Bai, C., Kusi -Sarpong, S., Sarkis, J. (2017). An implementation path for green information technology systems in the Ghanaian mining industry. J. Clean. Prod. 164, 1105-1123.

Berkhout, F., Hertin, J. (2001). Impacts of Information and Communication Technologies on Environmental Sustainability: Speculations and Evidence. OECD Report, 21, University of Sussex, Brighton.Bohas, A., Poussing N., 2016. An empirical exploration of the role of strategic and responsive corporate social responsibility in the adoption of different Green IT strategies. J. Clean. Prod. 122, 240-251.

Bergeron, F., Raymond, L. \& Rivard, S. (2004), Ideal patterns of strategic alignment and business performance, Information \& Management, 41(8), 1003-20.

Borghans, L., Heckman, J.J., Golsteyn, B.H.H., Meijers, H. (2009). Gender Differences in Risk Aversion and Ambiguity Aversion. J. Eur. Econ. Assoc. 7(2-3), 649-658.

Bose, R., Luo, X. (2011). Integrative framework for assessing firms' potential to undertake Green IT initiatives via virtualization - A theoretical perspective. J. Strategic Inf. Syst. 20, 38-54.

Boudreau, M.C., Watson, R.T., Chen, A.J. (2008). From Green IT to Green IS. Cutter Benchmark Rev. 85, 5-11.

Busch, T., Hoffmann, V.H. (2011). How Hot Is Your Bottom Line? Linking Carbon and Financial Performance. Bus. Soc. 50(2), 233-265.

Boediono. (2010). Jangan Bikin Laporan Aneh-Aneh. Nasional. Melalui http:// nasional.kompas.com/read/2010/04.

Casolaro, L. (2007). Information Technology and Productivity Changes in the Banking Industry. Econ. Notes 36 (1), 43-76.

Chen, A.J., Watson, R.T., Boudreau, M.C., Karahanna, E. (2011). An institutional perspective on the adoption of IT for Green and IT. Australas. J. Inf. Syst. 17(1), 23-44.

Chuang, S.P., Huang, S.J. (2016). The Effect of Environmental Corporate Social Responsibility on Environmental Performance and Business Competitiveness: The Mediation of Green Information Technology Capital, J. Bus. Ethics (forthcoming). 
The influence of information technology covid-19 plague against Financial Statements and Business Practices Lesi \& Safkaur

Chen, C. J. (2007), Information technology, organizational structure, and new product development: the mediating effect of cross-functional team interaction, IEEE Transactions on Engineering Management, 54(4), 678-698.

Ciborra, C. U. (1997), Improving in the shapeless organization of the future, Steps to the Future: Fresh Thinking on the Management of IT-Based Organizational Transformation, JesseyBass Publishers, San Francisco, CA. pp. 257-277.

Ciliberto, F. (2006), Does organizational form affect investment decisions?, Journal of Industrial Economics, 54(1), 63-93.

Cliffs, NJJean, R., Sinkovics, R. \& Kim, D. (2008), Information technology and organizational performance within international business to business relationships: a review and an integrated conceptual framework, International Marketing Review, 25(5), 563-83.

Crichton, E. \& Edgar, D. (1995), Managing complexity for competitive advantage: an IT perspective, International Journal of Contemporary Hospitality Management, 7(2/3), 12 18.

Croson, R., Gneezy, U., 2009. Gender differences in preferences. J. Econ. Lit. 47, 448-474.Dao, V., Langella, I., Carbo, J., 2011. From green to sustainability: Information Technology and an integrated sustainability framework, J. Strategic Inf. Syst. 20 (1), 63-79.

Corbett, J. (2010). Unearthing the value of Green IT. ICIS 2010 Proceedings, Paper 198.

Dedrick, J., 2010.Green IS: Concepts and Issues for Information Systems Research. Commun. Association Inf. Syst. 27 (1), 173-184.

Deng, Q., Ji, S., Wang, Y., 2017. Green IT practice disclosure: An examination of corporate sustainability reporting in IT sector. J. Inf. Com. Ethic. Soc. 15(2), 145-164.

Diana, G.C., Jabbour, C.J.C., Lopes de Sousa Jabbour, A.B., Kannan, D., (2017). Putting environmental technologies into the mainstream: Adoption of environmental technologies by medium-sized manufacturing firms in Brazil. J. Clean. Prod. 142, 4011-4018.

Dibrell, C.C. \& Miller, T. R. (2002), Organization design: the continuing influence of information technology, Management Decision, 40(6), 620-627.

Doran, J., Ryan, G. (2012). Regulation and firm perception, eco-innovation and firm performance. Eur. J. Innov. Man. 15 (4), 421-441.

Imam G. (2006) Aplikasi Analisis Multivariate dengan Program SPSS, Edisi 3, Badan Penerbit Universitas Diponegoro, Semarang.

Imam G., 2008, Structural Equation Modeling Metode Alternatif dengan Partial Least Square. Edisi 2, Badan Penerbit Universitas Diponegoro, Semarang.

Hair, J.F., Anderson, R.E., Tatman, R.L. \& Black, W.C (1998), Multivariate Data, Analysis with Reading, 5th ed Prentice-Hall, Englewood

Harry Nadir. (2010). Bakrie Diduga Salah Terapkan Akuntani. Ekonomi. Melalui http://bisniskeuangan.kompas.com/read/2010/07/21.

Hasan Bisri. (2010). Ada Rekayasa Akuntansi dalam Kasus Bank Century. Ekonomi. Melalui http://bisniskeuangan.kompas.com/read/2010/01/04.

Hertati, L (2015). Competence of Human Resources, The Benefits of Information Technology on Value of Financial Reporting in Indonesia. Research Journal of Finance and Accounting www.iiste.org.ISSN 2222-1697 (Paper) ISSN 2222-2847 (Online) Vol.6, No.8, 2015.

Hertati, L (2015). Impact of uncertainty of environmental and organizational culture on accounting information management systems and implications for managerial performance proposing a conceptual framework. International Journal of Economics, Commerce and 
The influence of information technology covid-19 plague against Financial Statements and Business Practices Lesi \& Safkaur

Management United Kingdom Vol. III, Issue 12, December 2015 Licensed under Creative Common Page 455 http:/ /ijecm.co.uk/ ISSN 23480386.

Hertati. L. (2015). Total Quality Management As Technics on Strategic Management Accounting. International Journal of Recent Advances in Multidisciplinary Research Vol. 02, Issue 11, pp.0942-0949, November, 2015.

Hertati, L. (2015). Internal Control And Ethics Of Quality Management Accounting Information Systems And Implications On The Quality Of Accounting Information Management: Proposing A Research Framework. International Journal of Economics, Commerce and Management United Kingdom Vol. III, Issue 6, June 2015 Licensed under Creative Common Page 902 http://ijecm.co.uk/ ISSN 23480386.

Hertati, L. (2016). Just In Time, Value Chain, Total Quality Management, Part Of Technical Strategic Management Accounting. International Journal of Scientific \& Technology Research Volume 5, Issue 04, April 2016 Issn 2277-8616.

Hertati. L. Syafarudin.A (2018). How the Implementation of the Industrial Revolution 4.0 Management Information System Influenced Innovation: The Case of Small and Medium Enterprises in Indonesia. Journal of Asian Business Strategy. 2018 3(4) 52-62.

Hertati.L, Susanto. A, Zarkasyi.W, Suharman. H, Umar.H. (2019). The Effect of Human Resource Ethics on Financial Reporting Implications for Good Government Governance (Survey of Related Sub-units in State-owned Enterprises in SUMSEL). International Journal of Economics and Financial Issues ISSN: 2146-4138 available at http: www.econjournals.com International Journal of Economics and Financial Issues, 2019, 9(4), 267-276.

Hertati.L, Susanto. A, Zarkasyi.W, Suharman. H, Umar.H. (2019). Pengujian Empiris Bagaimana Kualitas Sistem Informasi Akuntansi Yang Dipengaruhi Oleh Etika Organisasi Berimplikasi Terhadap Kualitas Informasi Akuntansi (Surveypada Badan Usaha Milik Negara (Bumn) Di Sumatera Selatan Indonesia). Jurnal Ilmiah Akuntansi Rahmaniyah (JIAR) Vol. 3 No.1, Desember 2019, 88 - 107.

Hertati, L Safkaur, O, Simanjuntak. M.A. (2020). How to Align Management Commitments to the Successful Implementation of Management Accounting Information Systems in Manager Decision Making. IJTC Ilomata International Journal of Tax \& Accounting P-ISSN: 27149838; E-ISSN: 2714-9846 Vol. 1 No. 2 March 2020 Pp : 89-102 https://www.ilomata. org/index.php/ijtc.

Ito Warsito. 2010. Bakrie Diduga Salah Terapkan Akuntani. Ekonomi. Melalui http://bisnis keuangan. kompas.com/read/2010/07/21.

Koontz,H. and Weihrich, H. (1990), Essentials of Management, 5th ed., McGraw-Hill, NewYork, NY.

Law, R. \& Jogaratnam, G. (2005), A study of hotel information technology applications, International Journal of Contemporary Hospitality Management, 17(2), 170-80. ntexts, Information \& Management, 35(1), 43-51.

Lotti, R., Mensing, P. \& Valenti, D. (2006), A co-operative solution, Strategy+Business, May, available at: www.strategy-business.com/article/06209 MeijaardSmall Business Economics, 25(1), 83-96.

Miesing, P. (2006), Organizational Structure for the Learning Organization, School of Business, University Albany/Suny, Albany, NY. Moralesperformance through organizational learning Technovation, 27(9), 547-68. 
The influence of information technology covid-19 plague against Financial Statements and Business Practices Lesi \& Safkaur

Mulyani.S. 2008. Depkeu dan BPK Perlu Sehati. Ekonomi. Melalui http://bisnis keuangan.kompas.com.

Mulyani.S.2009. Sri Mulyani Ragukan Data BI. Ekonomi. Melalui http://bisniskeuangan. kompas.com/read/2009/09/25.

Nunnally, J.C. \& Bernstein, I.H. (1994), Psychometric Theory, 3rd ed., McGraw-Hill, New York, NY. Panayides, P.M. (2007), The impact of organizational learning on relationship orientation, logistics service effectiveness and performance, Industrial Marketing Management, 36(1), 68-80.

Ragowsky, A., Ahituv, N. \& Neumann, S. (1996), Identifying the value and importance of an information system application, Information \& Management, 31(2), 89-102.

Richard, P.J., Devinney, T.M., Yip, G.S. \& Johnson, G. (2009), Measuring organizational performance: Towards methodological best pra ctice, Journal of Management, 35(3), 718804. Sakalas, A. \& Venskus, R. (2007), Interaction of learning organization and organizational structure, Engineering Economics, 3(53), 65-70.

Stewart, R.A. (2007), IT enhanced project information management in construction: pathways to improved performance and strategic competitiveness, Automation in Construction, 16(4), $511-17$.

Susanto. A. (2017). Sistem Informasi Manajemen: Pendekatan Terstruktur Resiko Pengembangan. Bandung: Lingga Jaya.

Susanto.A. (2017). Sistem Informasi Akuntansi: Struktur-Pengendalian-Resiko- Pengembangan. Bandung: Lingga Jaya.

Tavitiyaman, P., Zhang, H. Q. \& Qu, H. (2012), The effect of competitive strategies and organizational structure on hotel performance, International Journal of Contemporary Hospitality Management, 24(1), 140-159.

Teixeira, R., Koufteros, X., Peng, X. \& Schroeder, R. (2008), The relationship between organizational structure and integration: the effects on manufacturing performance, paper presented at 39th Decision Science Annual Meeting, Baltimore, MD. Whisler, T. L. (1970), The Impact of Computers on Organizations, Praeger Publishers, New York, NY. 